\title{
Suplementasi Probiotik (Lactobacillus plantarum) dalam Sari Buah Sebagai Alternatif Produk Pangan Fungsional
}

\author{
Ernanin Dyah Wijayanti ${ }^{1}$, Ambar Fidyasari ${ }^{2}$, Fitri Eka Lestari ${ }^{2}$ \\ 1) Akademi Farmasi Putra Indonesia Malang \\ 2) Akademi Analis Farmasi dan Makanan Putra Indonesia Malang
}

\begin{abstract}
Most of probiotic product as functional food were developed from dairy product. However, milk protein content cause allergy and make it limited to non vegetarians only. To solve these problems, some efforts were tried to produce probiotic drink from fruit juice, such as pineaple, tomato, papaya and aple. The aims of this research were to know the quality of probiotic fruit juice organoleptically and the viability of probiotic in it. Lactobacillus plantarum were used as probiotic and the fermentation process were last for 5 days at $30^{\circ} \mathrm{C}$. The results showed that the best quality performed by fermented aple juice, with sour taste, pale brown color, aple fermented aroma and good homogenity. The probiotic viability also showed highest number, $1,7 \times 10^{8} \mathrm{cfu} /$ $\mathrm{ml}$. This research can be developed to produce fermented fruit juice with better quality.
\end{abstract}

Keywords: fruit juice, organoleptic, probiotic, viability

\begin{abstract}
ABSTRAK
Sebagian besar produk probiotik untuk pangan fungsional selama ini dikembangkan melalui suplementasi pada dairy product (produk berbahan dasar susu), sehingga tidak dapat dikonsumsi oleh vegetarian dan orang yang alergi terhadap protein susu. Hal ini menjadi pertimbangan untuk mengembangkan minuman probiotik dari bahan non dairy, misalnya buahbuahan yang jumlahnya melimpah dengan harga yang terjangkau, antara lain nanas, tomat, pepaya dan apel. Penelitian ini bertujuan untuk mengetahui kualitas organoleptis minuman sari buah yang disuplementasi dengan probiotik dan viabilitas probiotik dalam minuman tersebut. Probiotik yang digunakan adalah Lactobacillus plantarum, dengan proses fermentasi selama 5 hari pada suhu $30^{\circ} \mathrm{C}$. Hasil penelitian menunjukkan bahwa sari buah apel terfermentasi mempunyai kualitas organoleptis yang paling baik yaitu rasa asam, warna kecoklatan, aroma khas apel terfermentasi dan homogenitas yang sesuai. Selain itu, viabilitas probiotik pada sari buah apel juga paling baik, yaitu mencapai $1,7 \times 10^{8} \mathrm{cfu} / \mathrm{ml}$. Penelitian ini merupakan penelitian eksploratif tahap awal, yang diharapkan dapat dikembangkan untuk menciptakan produk minuman sari buah terfermentasi dengan kualitas optimal.
\end{abstract}

Kata kunci: organoleptis, probiotik, sari buah, viabilitas 


\section{Latar Belakang}

Gaya hidup masyarakat yang serba instan menyebabkan perkembangan berbagai macam penyakit degeneratif dan masalah pencernaan. Hal ini mendorong semakin berkembangnya pangan fungsional yang bertujuan untuk mencegah berbagai gangguan kesehatan, memperbaiki fungsifungsi fisiologis sehingga dapat melindungi tubuh dari penyakit-penyakit tertentu. Pangan fungsional yang dikembangkan adalah makanan yang dapat dikonsumsi sebagaimana layaknya makanan sehari-hari, sehingga yang dikonsumsi oleh masyarakat akan lebih bervariasi. Hal tersebut juga dapat mendukung tercapainya program diversifikasi pangan. Salah satu produk pangan fungsional adalah bahan makanan yang mengandung probiotik.

Probiotik didefinisikan sebagai mikroba hidup yang mempunyai efek menguntungkan pada inang (host) untuk memperbaiki keseimbangan mikroba intestinal dan mempunyai berbagai macam fungsi kesehatan, diantaranya adalah mengatasi masalah infeksi intestinal, mereduksi kadar kolesterol maupun LDL (Sudha dkk, 2009).

Sebagian besar produk probiotik selama ini dikembangkan melalui suplementasi pada dairy product (produk berbahan dasar susu), misalnya yogurt, keju, kefir dan lain-lainnya. Pengembangan minuman kesehatan yang mengandung probiotik dari bahan non dairy belum banyak dikembangkan. Hal ini terkait dengan kegunaan pangan fungsional yang pada hakekatnya harus mampu diakses oleh berbagai kalangan. Adanya fenomena vegetarian, alergi pada produk berprotein serta nilai ekonomis susu yang cukup tinggi, menyebabkan produk probiotik berbahan dasar susu masih belum dapat diakses oleh berbagai kalangan. Cargill (2009) dalam Granato dkk. (2010) menyatakan bahwa sari buah dan produk berbahan dasar sereal yang disuplementasi probiotik dapat menjadi media lain yang cocok untuk aplikasi probiotik. Sheehan dkk., 2007 dalam Granato dkk. (2010) menambahkan bahwa buah dan sayur mengandung nutrisi yang bermanfaat, seperti mineral, vitamin, serat pangan dan antioksidan, serta tidak mengandung alergen hewani yang mungkin dihindari oleh segmen tertentu dari suatu populasi.

Berdasarkan hal-hal yang telah dijelaskan di atas, maka perlu dilakukan suatu inovasi produk probiotik dengan memanfaatkan buah-buahan yang ketersediaannya melimpah sepanjang tahun dan harganya terjangkau, misalnya apel, nanas, pepaya dan tomat. Buah-buahan tersebut dipergunakan dalam bentuk sari buah yang selanjutnya difermentasi menggunakan bakteri probiotik.

Penelitian ini bertujuan untuk mengetahui kualitas organoleptis minuman sari buah yang disuplementasi dengan probiotik dan viabilitas probiotik dalam minuman tersebut. Penelitian ini diharapkan mampu memperkaya varian produk pangan fungsional yang mudah dibuat dan didapat, sehingga bisa dipergunakan untuk menunjang proses terapi terutama di bidang kesehatan.

\section{Metode Penelitian}

\section{Bahan dan Kultur}

Bahan untuk minuman sari buah antara lain apel, nanas, pepaya dan tomat, sedangkan bakteri probiotik yang digunakan adalah Lactobacillus plantarum yang ditumbuhkan pada media MRS broth dan digunakan sebagai inokulum. 


\section{Pembuatan sari buah}

Buah yang telah dikupas (kecuali tomat) dicuci kemudian diblanching selama 5 menit pada suhu $80^{\circ} \mathrm{C}$. Selanjutnya diblender dengan menambahkan air, disaring dan disterilkan pada suhu $110^{\circ} \mathrm{C}$ selama 10 menit.

\section{Fermentasi sari buah yang disuplementasi probiotik}

Inokulum Lactobacillus plantarum ditambahkan pada sari buah, kemudian dihomogenkan dan diinkubasi selama 5 hari pada suhu $30^{\circ} \mathrm{C}$.

Uji organoleptik sari buah yang disuplementasi probiotik

Masing-masing sari buah yang telah terfermentasi diuji organoleptis yang meliputi warna, tekstur, aroma dan rasa.

\section{Uji viabilitas probiotik dalam sari buah}

Uji viabilitas dilakukan dengan metode Total plate count menggunakan media MRS agar.

\section{Hasil dan Pembahasan}

Penelitian ini menggunakan buahbuahan antara lain pepaya, nanas, apel dan tomat, dengan pertimbangan bahwa buahbuahan tersebut tersedia sepanjang tahun dan jumlahnya melimpah sehingga akan lebih mudah diperoleh untuk pengembangan produksi minuman probiotik sari buah dalam skala besar. Selain alasan tersebut, buah-buahan yang telah disebutkan di atas juga memiliki kandungan serat pangan yang dapat berperan sebagai prebiotik, dimana prebiotik tersebut akan mendukung pertumbuhan bakteri probiotik baik selama fermentasi maupun ketika berada dalam saluran pencernaan (ketika sudah dikonsumsi).

Bakteri yang digunakan untuk fermentasi sari buah yaitu Lactobacillus plantarum dari golongan bakteri asam laktat, dimana bakteri tersebut sudah terbukti sebagai probiotik dan berdasarkan penelitian sebelumnya, bakteri tersebut mampu memfermentasi bahan non-dairy, yaitu sereal (Molin, 2001).

Hasil penelitian menunjukkan bahwa sari buah yang telah difermentasi tampak lebih keruh dari sari buah sebelum fermentasi, yang menunjukkan pertumbuhan dan hasil metabolisme bakteri asam laktat dalam sari buah. Sedangkan hasil uji organoleptis dapat dilihat pada Tabel 1.

Sari buah apel terfermentasi memiliki kualitas organoleptis yang paling baik diantara sari buah yang digunakan, hal ini ditunjang dengan hasil uji viabilitas tertinggi pada sari buah apel yaitu sebesar $1,7 \times 10^{8}$ cfu/ml (Gambar 1).

Tabel 1. Hasil uji organoleptis minuman probiotik sari buah

\begin{tabular}{lllll}
\hline Parameter & Sari pepaya & Sari nanas & Sari apel & Sari tomat \\
\hline Warna & Oranye & Kuning muda & Coklat muda & Merah \\
Tekstur & Kurang & Kurang & Homogen & Tidak \\
& homogen & homogen & & homogen \\
Aroma & $\begin{array}{l}\text { Pepaya } \\
\text { terfermentasi }\end{array}$ & $\begin{array}{l}\text { Nanas } \\
\text { terfermentasi }\end{array}$ & Apel & $\begin{array}{l}\text { Tomat } \\
\text { terfermentasi }\end{array}$ \\
& Sangat asam & Sangat asam & Sangat asam & kurang sedap \\
& Sangat asam \\
\hline
\end{tabular}




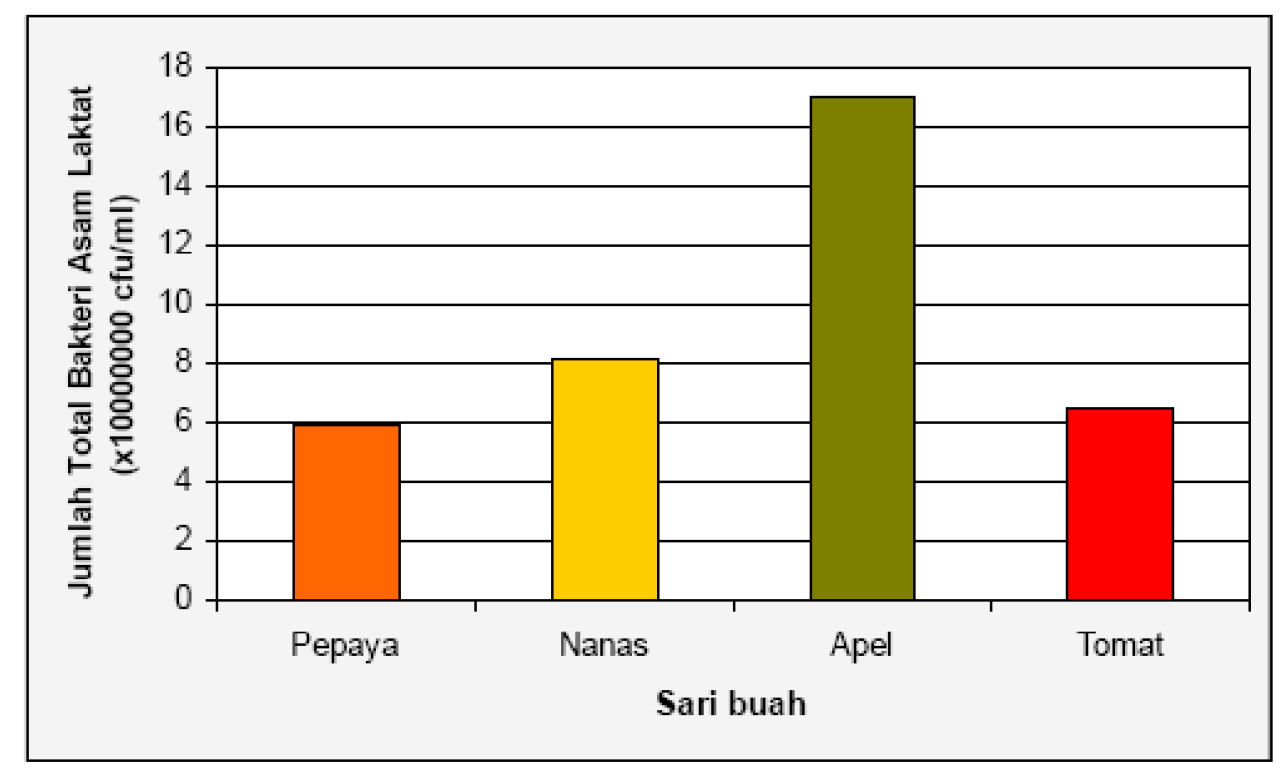

Gambar 1. Hasil uji viabilitas probiotik dalam sari buah

Hal ini menunjukkan bahwa sari buah apel sesuai untuk pertumbuhan $L$. plantarum. Dengan jumlah awal bakteri yang sama untuk proses fermentasi, sari buah apel mampu mempertahankan viabilitas bakteri tersebut hingga akhir proses fermentasi. Sebagai minuman probiotik, viabilitas bakteri asam laktat merupakan parameter yang sangat penting karena probiotik merupakan satu-satunya kandungan yang diutamakan dalam sari buah yang telah difermentasi. Bakteri inilah yang akan memberikan manfaat pada tubuh, terutama saluran pencernaan apabila minuman probiotik sari buah tersebut dikonsumsi.

Standar yang dikembangkan oleh Fermented Milks and Lactic Acid Bacteria Beverages Association menetapkan bahwa produk yang mengandung $3 \times 10^{7}$ bifidobacteria/g atau per $\mathrm{mL}$ dipertimbangkan sebagai makanan probiotik (a probiotic food). Untuk menunjukkan klaim keuntungan bagi nutrisi dan kesehatan yang dipunyai bakteri probiotik harus viabel dan berada dalam jumlah yang tinggi pada saat dikonsumsi. Selanjutnya mereka harus tetap hidup di bagian akhir saluran gastrointestinal. Untuk alasan tersebut produk atau probiotik adjunct (pembawa probiotic) harus mengandung tidak kurang $10^{6} \mathrm{CFU} / \mathrm{ml}$ bakteri probiotik pada saat dikonsumsi (Blanchette et al., 1996). Jumlah tersebut dapat bertahan dalam saluran pencernaan dan memberikan manfaat bagi inang apabila produk probiotik dikonsumsi secara terus-menerus. Hal ini sesuai yang dikemukakan Pavan dkk. (2003), bahwa bakteri asam laktat yang berpotensi sebagai probiotik mampu bertahan selama beberapa hari pada saluran pencernaan. Jumlah bakteri tersebut akan menurun dengan cepat apabila pemberian probiotik dihentikan.

Viabilitas probiotik yang cukup stabil dalam sari buah apel membuktikan bahwa sari buah apel sesuai dengan lingkungan hidup Lactobacillus plantarum dan nutrisi yang terdapat pada sari buah apel cukup tersedia selama proses inkubasi, sehingga Lactobacillus plantarum mampu bertahan hidup dan melakukan aktivitas metabolisme dengan memanfaatkan nutrisi yang terdapat dalam sari buah apel. 


\section{Kesimpulan}

Studi yang telah dilakukan menunjukkan bahwa keempat buah yang digunakan yaitu pepaya, nanas, apel dan tomat memiliki potensi untuk dikembangkan sebagai minuman probiotik sari buah, terutama buah apel dimana sari buah terfermentasi yang dihasilkan memiliki kualitas organoleptis yang paling baik, antara lain aroma apel terfermentasi, rasa sangat asam, tekstur homogen dan warna coklat, dengan viabilitas probiotik yang paling tinggi pula yaitu mencapai $1,7 \times 10^{7}$ $\mathrm{cfu} / \mathrm{ml}$, sehingga memenuhi persyaratan sebagai minuman probiotik.

\section{DAFTAR PUSTAKA}

Blanchette, L, D. Roy, G. Belanger and S.F. Gauther, 1996. Production of cottage chese using dressing fermented by bifidobacteria.J. Dairy Sci. $79: 8-15$

Granato, D., G. F. Branco, F. Nazzaro, A. G. Cruz dan J. A. F. Faria. 2010. Functional Foods and Nondairy Probiotic Food Development: Trends, Concepts and Products. Comprehensive Reviews in Food Science and Food Safety Vol. 9: 292-302

Molin, Goran, 2001. Probiotic in foods not containing milk or milk constituents with specual refrence to Lactobacillus plantarum 299v. Am.J. Clin nUtr : 73(suppl): 380s$5 \mathrm{~s}$

Pavan, S., P. Desreumax dan A. Mercenier. 2003. Use of Mouse Models To Evaluate the Persistence, Safety and Immune Modulation Capacities of Lactic Acid Bacteria.
American Society for Microbiology. 10(4): 696-701

Sudha, M. R., P. Chauhan, K. Dixit, S. Babu, K. Jamil. 2009. Probiotics as Complementary Therapy for Hypercholesterolemia. Biology and Medicine. Vol. 1 (4): Rev 4 